\title{
The Sustainable Development of Miami: Tackling the Homeless Problem
}

\author{
Vaiva Kalesnikaite, Jean-Claude Garcia-Zamor \\ Department of Public Administration, Florida International University, Miami, USA \\ Email: vkale002@fiu.edu, garciaz@hotmail.com
}

Received 2 July 2014; revised 2 August 2014; accepted 1 September 2014

Copyright (C) 2014 by authors and Scientific Research Publishing Inc.

This work is licensed under the Creative Commons Attribution International License (CC BY).

http://creativecommons.org/licenses/by/4.0/

c) (i) Open Access

\begin{abstract}
The article intends to provide more understanding of strategies intended to tackle homelessness presence in Miami-Date County as well as draw some lessons that could be learnt from experience. It is explanatory in nature and the main method used is extensive literature research as well as the official reports. It discusses the issue of homelessness in the light of sustainable communities; overviews the important strategies for tackling homelessness presence in the literature and practice; discusses the homelessness presence in Miami-Date County and the strategies and main actors that tackle it; discusses the sustainability of these strategies in the light of development of Miami-Dade County; and draws conclusions and suggestions for strategies of tackling homeless presence in Miami-Dade County.
\end{abstract}

\section{Keywords}

Homelessness, Sustainable Communities, Accommodation, Criminalization, Urbanization

\section{Introduction}

Sustainable development was defined in the Brundtl and Report of the United Nations (UN) as the "development that meets the needs of the present without compromising the ability of future generations to meet their own needs" (United Nations, 1987). The challenges for sustainable development are faced by both developing and developed nations, and involve a wide array of issues, such as sustainable consumption of resources, sustainable urban planning, food security, or tackling environmental problems.

According to Cozens (2002), tackling homelessness is an important issue of sustainable development in communities as it would assure advancement in quality of life and promoting social equity across the present and future generations (Cozens, 2002). As citizens across the Western countries are embracing sustainability in various aspects of their lives, especially urban planning and the use of recourses, more attention should be drawn 
towards the sustainable communities and a person's well-being (Roseland, 2012). Sustainable community is an important component of sustainable development as it is essential to attaining safe and secure society in both developed and developing nations (Hombs, 2001).

The article therefore focuses on the issue of homelessness and strategies that intend to tackle homelessness. The case study of Miami-Dade County is conducted, and the issues of sustainable solutions to homeless presence are discussed. As of 2013, there were 3,734 homeless persons in official report from the Council of Homelessness in Miami-Dade (Council on Homelessness, 2013).

The article intends to provide more understanding of strategies intended to tackle homelessness presence in Miami-Date County as well as draw some lessons that could be learnt from experience. It is explanatory in nature and the main method used is extensive literature research as well as the official reports.

In order to accomplish the goal established, the following tasks are set in the article:

1) To discuss the issue of homelessness in the light of sustainable communities;

2) To overview the important strategies for tackling homelessness presence in the literature and practice;

3) To discuss the homelessness presence in Miami-Date County and the strategies and main actors that tackle it;

4) To discuss the sustainability of these strategies in the light of development of Miami-Dade County;

5) To draw conclusions and suggestions for strategies of tackling homeless presence in Miami-Dade County.

\section{Sustainable Communities and Homelessness}

The importance of sustainable development has been sweeping across the world, both in Europe and North America. Planners are attempting to create sustainable buildings, cities, and regions, where development can benefit local communities (Raco, 2007). However, in order to create sustainable communities, a number of issues have to be tackled, such as youth unemployment, alcoholism, drug use, social exclusion, and crime.

As suggested in the introduction, tackling homelessness is a vital part of creating sustainable communities, as according to Hombs (2001), on the national level, reducing homelessness helps prevent crime and on the international level, it would promote peace and security (Hombs, 2001). Thompson (2005) provides two main components of sustainable communities: first, social capital, and, second, natural capital. Social capital refers to the shared knowledge, patterns of interaction between people, and is largely connected to the ability of community members to trust one another. Natural capital refers to natural resources, housing, transportation, and opportunities for economic development (Thompson, 2005).

It is evident that the social capital closely deals with the issue of homelessness, as high homelessness presence might result in higher crime rates, public storing of belongings, and lower levels of social capital. Calsyn and Morse (1991) studied the lack of social capital in homeless persons and conducted an empirical analysis trying to explain the factors that contribute the most to chronic homelessness. The researchers found that the length of being homeless was strongly associated with the lack of human capital and social alienation (Calsyn \& Morse, 1991). Calsyn and Morse (1991) report that homelessness was also closely associated with stressful life events. As a result, it becomes hard for homeless people to voice their concerns and interests while community plans are being made. Harding and Willet (2008) therefore ask a question as who is exactly included and excluded from community planning when trying to establish sustainable communities (Harding \& Willet, 2008).

According to Flint and Raco (2012), the impacts of sustainable development initiatives on the most vulnerable communities are rarely assessed, which are in most need of assistance (Flint \& Raco, 2012). Usually, the challenges that cities face in sustainable development initiatives are very well connected to vulnerable groups, but overlooked. Flint and Raco (2012) argue that homelessness is not sufficiently addressed in the literature and practice of sustainable development initiatives. Similarly when discussing the development of sustainable communities, Dale and Newman (2010) emphasize the challenges that are usually faced during the process: public health, access to long-term maintenance of resources, improving infrastructure, fragmentation, and economic disparities (Dale \& Newman, 2010). Homelessness can be identified as an issue of economic disparities, where a certain group of members of society lack basic resources to lead quality lives.

According to the typology of problems that the development planners face by Rittel and Webber (1973), homelessness could be seen as what they identify as a "wicked problem". A few characteristics of this type of a problem well corresponds with the issue of homelessness (Rittel \& Webber, 1973):

1) there is no evident formulation of a wicked problem as the solutions that are proposed for it usually define 
the problem itself, for instance, when defining the problem of homelessness, it is not possible to develop all possible solutions ahead of time;

2) the wicked problems have no stopping rule of solution and usually depend on the criteria that is decided by the planner as always "better" can be done;

3) there is no immediate solution to the wicked problem, such as for homelessness, the problem has to be addressed from a few different angles;

4) every wicked problem can be considered to be a symptom of another problem, as in terms of homelessness, it is usually caused by alcoholism, drug use, lack of income, or social exclusion.

Therefore, the typology suggests that there is no quick solution to the problem, but in order to promote sustainable communities, the issue has to be addressed. According to Flint and Raco (2012), who view the issue of homelessness from the sustainable community perspective, it is not enough to simply mention social equity issues in development plans to solve homelessness problem: usually, the economic and political forces limit concerns for social equity (Flint \& Raco, 2012). Although sustainability is connected to integrating economic, environmental, and equity components, equity might be pushed away from the priorities of political agenda due to the interests at play. It is especially evident in the Miami-Dade County, where there is evident priority for economic growth and homeless criminalization has been on the rise in the recent years.

\section{Strategies to Tackle Homeless Presence}

The literature on homelessness and strategies for tackling homeless presence is scarce. Probably the most comprehensive report on homelessness was published by the UN Centre for Human Settlements (Habitat) of 2000 (UN, 2000). The reports points out important issues when understanding the homeless issue and developing strategies to reduce the numbers of homeless worldwide. First, homeless is a pragmatic term-there is no one, agreed upon definition of who is homeless, and varies widely across the developing and developed countries. Some definitions are concentrated on the lack of housing, while others also include the people in risk of becoming homeless. For this reason, the UN provides two definitions, one for the developed high-income industrial countries, and one for the developing countries. While in the developing countries, the numbers of homeless are usually established with the regard to people that lack permanent housing, in industrial developed countries, usually both people that lack permanent housing and are in risk of losing housing facilities are included in the homeless counts (UN, 2000).

It is important to note that major challenges are experienced when trying to establish adequate numbers of homeless presence across countries: the numbers of homeless in any given country or entity are usually distorted due to lack of clear definitions, undercounting, the problem of homeless mobility, and the hidden homeless, as in some instances, such as illegal immigration, the homeless might actively be hiding from the authority in order not to be arrested or deported (UN, 2000).

In the literature, two main strategies to tackle homeless presence are found: accommodation and criminalization, or as Slumsky (2012) refers to, handcuffs as opposed to homes (Slumsky, 2012).

\subsection{Accommodation}

Accommodation refers to the approach to solve the homeless issue by providing the homeless temporary and permanent housing, with the help of social programs and work training in order to reintegrate the homeless into the society. It is also pointed out as the main strategy by the UN Centre for Human Settlements (Habitat): "[i]n order to be successful, strategies to combat homelessness need to be based on a public policy framework that incorporates employment policy and housing policy, as well as social safety nets and housing allowances" (UN, 2000: p. 4). Accommodation can be seen as one of the sustainable solutions to tackle homelessness, which is directed to helping homeless people reintegrate into the society with providing them adequate housing, helping to battle addictions, provide basic work skill training, and a social worker to support homeless persons through the process. According to Homelessness International, homelessness is closely associated with poverty and dealing with homelessness in a sustainable sense requires investments in adequate shelter that is sustainable in economic, social, and environmental sense (Levinson, 2004). Therefore, providing the homeless with accommodation is not enough: homelessness is associated with a lack of basic work skills, mental issues, and substance abuse, which has to be addressed according to each person's need, by counseling, meetings, and with the help of an assigned caseworker. 
There are two main approaches of homeless housing: first, the programs that provide permanent housing to homeless people prior to addressing other issues they may be experiencing, and, second, programs that have different levels of housing, and in order for a homeless person to be provided with permanent housing, they have to fulfill certain criteria and demonstrate certain progress.

The importance of accommodation and counseling to tackle homelessness was been researched by Craig and Hodson (2000), who conducted interviews with the homeless people as they were given accommodation, and followed-up a year after. They found that homeless people, who prone to substance abuse, was associated with poor accommodation outcome (Craig \& Hodson, 2000).

A success story in dealing with homeless presence by providing accommodation can be attributed to the state of Utah. Utah has successfully decreased the percentage of chronically homeless persons from 2000 to 2008 by $74 \%$ by simply providing the homeless population with apartments. The state of Utah employed the Housing First approach, which prioritizes the need of chronically homeless persons to first gain adequate living space before addressing any other issues they might be facing (Utah Housing and Community Development Division, 2012). The Housing First program was launched after it was established that providing homeless people with apartments and social workers cost the state less than yearly emergency room expenses and arrests. Each person receiving an apartment is assigned a caseworker to help them become self-sufficient. However, even in case of failure to become self-sufficient, the persons can still keep their apartments (Utah Department of Community Services and Economic Development, 2004).

Utah has plans to end chronic homelessness by 2015, and so far there has been a significant decrease in chronic homeless living on the streets. The success of the plan also lies within the scope of the Housing First, which is implemented statewide. Utah has, as a result, become an example of employing sustainable solutions towards tackling chronic homelessness.

\subsection{Criminalization}

Homeless criminalization can be defined as official law enforcement activity in order to place restrictions on homeless people behavior, such as sleeping in public places, storing private items, or panhandling (Cunningham, 1999). The National Law Center on Homeless and Poverty (NLCHP) reports the types of usual criminalization measures in the US: laws that prohibit sleeping, storing personal belongings in public spaces; laws that prohibit panhandling in order to drive out the homeless population out of cities and downtowns; and sweeps in city areas where homeless people live in order to drive them out of particular areas (NLCHP, 2014). According to the NLCPH, homeless criminalization has been on the rise in the US in the recent years, with $7 \%$ increase in laws prohibiting camping in public places, $11 \%$ increase in laws prohibiting loitering in public places, $6 \%$ increase in laws prohibiting panhandling, and 5\% increase in laws prohibiting aggressive panhandling (NLCHP, 2014). According to the report, four cities that enacted the strictest anti-homeless laws were in Florida: St. Petersburg, Orlando, Gainesville, and Bradenton (NLCHP, 2014).

Criminalization can be closely associated with forced gentrification (Amster, 2003). The term gentrification, first coined by Glass (1964), refers to the process when the middle-class moves back into the city from the suburbs (Frank, 2002). However, it has been greatly expanded with new challenges in urban development and is used to describe the process of urban revitalization, when with an influx of highly educated young professionals, and urban planning initiatives, the value of property increases greatly and the lower-income individuals are forced out of the area by being unable to afford rent or property taxes. In terms of homelessness, Levinson (2004) reports that gentrification usually causes homelessness and displaces vulnerable residents from the area (Levinson, 2004). Also, the process may sometimes cause the foreclosure of homeless shelters, as in Cincinnati, where a shelter that housed 16,000 people was closed to make place for a new Fine Arts and Education Center (Levinson, 2004). The homeless people are displaced with concerns that they could potentially harm the face of the new community, tourism and businesses. Bella and Lopez (1994) report that homeless criminalization results from the government's interest to maintain the public places attractive to citizens and visitors, however, as a result, it causes the minority, or homeless, suppression (Bella \& Lopez, 1994).

Criminalization, therefore, can be viewed as a form of gentrification, when homeless people are forced from certain areas by being unable to exercise the life-sustaining everyday activities. Rather than employing sustainable means of tackling homelessness, the proponents of homeless criminalization intend to force them out of some public places, or even cities. Homeless criminalization can be employed as means of city beautification, as 
in Miami-Dade case, which is discussed in further chapters, with rapidly developing Downtown Miami, the homeless have been stripped off some previously exercised rights in order to decrease the homeless presence in the eyes of tourists, business owners, and residents in the area.

Another practice that King and Dunn (2004) examine is the police-initiated trans-jurisdictional transport (King \& Dunn, 2004). King and Dunn (2004) report that the City of Miami has been a popular destination to transport homeless people for local municipalities in 2001, where the local police agencies transported homeless persons and left them at Downtown Miami homeless centers (King \& Dunn, 2004). As a result, the downtown Miami has a large homeless presence, which is also associated with a large concentration of homeless service providers in the area.

\section{Homelessness in the US}

According to Rossi (2013), in order to properly address a social problem, there has to be sufficient data to determine whether a phenomenon can be held as a social problem in general (Rossi, 2013). However, in terms of homelessness in the US, both data and a clear definition are lacking. The US Department of Housing and Urban Development (HUB) identifies homeless people as: those, who do not have shelter, are in imminent risk of becoming homeless, are homeless under other Federal statutes, are fleeing or attempting to flee domestic violence (HUB, 2014). The HUB prepares a yearly report on homelessness prevalence in the US. In 2013, according to the report, there were 610,042 homeless people in the US; of which 65\% were living in emergency shelters or transitional housing programs and $35 \%$ were living in unsheltered locations. The largest homeless prevalence was in the state of California, 22\% of the national count, New York with 13\%, and Florida, with $8 \%$. The largest numbers of homeless people that lived in unsheltered locations were found in California, Florida, Arkansas, Nevada, Mississippi, and Oregon (HUB, 2013). Substance Abuse and Mental Health Services Administration (SAMHSA) indicated that the homeless population in the US consists of single individuals, families, children and veterans (SAMHSA, 2011).

\section{Homelessness in Miami-Date County}

According to the Council on Homelessness Report of 2013, there were 3,734 homeless people in Miami-Dade County in 2013. The majority of homeless were males (66\%), followed by $34 \%$ females. There has been a significant decline in homeless presence from 2005 to 2013, from 5,773 to 3,734 homeless people respectively (Council on Homeless, 2013). Table 1 shows the decline in homeless presence in Miami-Dade County over the last 7 years

According to the report, the following persons are officially considered as homeless in Miami-Dade County: first, people who live in publicly or privately operated shelters, second, people, whose primary residence is a private or public place not intended to use for accommodation for human beings, third, a person who is exiting an institution, where (s)he resided for 90 days or less, and who was homeless prior to entering the institution, fourth, a person who is fleeing from a domestic violence situation, fifth, a person who is to lose the place of residence within 14 days and has no resources to obtain another permanent housing (Council on Homeless, 2013). Therefore, as compared to the homeless people definition by the United Nations, Miami-Dade County employs the wider approach to homelessness, where both people that lack sufficient shelter and those in risk are considered homeless.

Although the official numbers of adult homeless people have been on decline, the numbers of homeless students in Miami-Dade County have increased significantly over the past few years. Table 2 shows the increase in homeless students in Miami-Dade County over several years.

However, the numbers of homeless population in Miami-Dade County should not be taken for granted. As explained in the previous chapters, establishing the real numbers is extremely difficult, and it largely depends on the method of data gathering. The records of individuals that were receiving homeless services at a certain point of time is a misleading technique as there might be many homeless people either constantly residing on the streets or hiding, due to their immigration status. Therefore, in the state of Florida, volunteers are employed that conduct surveys with people on the streets, parks, and other public places (Department of Community Affairs, 2013).

The main actor in Miami-Dade County that delivers services to the homeless is the Homeless Trust, founded in 1993. According to the official report of 2013, the Homeless Trust was delivering housing services to 2895 
Table 1. Homeless people in Miami-Dade County.

\begin{tabular}{lc}
\hline Year & Homeless Count \\
\hline 2007 & 4392 \\
2008 & 4574 \\
2009 & 4333 \\
2010 & 3822 \\
2011 & 3777 \\
2012 & 3817 \\
2013 & 3734 \\
\hline
\end{tabular}

Source: Council on Homelessness, Department of Children and Families (2013).

Table 2. Homeless students in Miami-Dade County.

\begin{tabular}{lc}
\hline Year & Homeless Count \\
\hline 2008 & 2382 \\
2009 & 2581 \\
2010 & 4268 \\
2011 & 4406 \\
2012 & 5773 \\
\hline
\end{tabular}

Source: Council on Homelessness, Department of Children and Families (2013).

homeless persons, of which there were 1407 people housed in an emergency shelter, 1362 in transitional housing, 30 in a shelter, 96 in a hotel or a motel, and 30 in Safe Haven family housing shelters.

The Homeless Thrust operates on a three-stage plan, where three main stages of services are offered, namely the emergency housing, or the temporary care, where the homeless can find shelter, food and clothes, transitional housing, where a homeless person is provided with six-to-nine month stay, including treatment, rehabilitation, employment and job training. Permanent, supported housing is the third stage, where homeless people are assisted with reintegration into the community and supported with long-term services (Homeless Trust, 2014).

According to Wright and Donley (2011), Homeless Trust is perceived as a success story in the US, which other cities try to replicate (Wright \& Donley, 2011). The scholars attribute the success of Miami Homeless Trust to the Housing First program, which, above all, place the largest emphasis on addressing the housing needs of the homeless, which is believed to be the first need of homeless persons that had to be addressed. The Homeless Trust therefore applies approaches of housing the homeless, transition, and permanent housing, as in Utah's case.

Homeless Trust secured considerable financing through the food and beverage tax (FBT), by adding a $1 \%$ tax to all transactions in restaurants that possess liquor license that gross $\$ 400,000$ or more in a year (HUB, 2010).

\section{Urbanization and Homelessness: The Case of Miami}

Sassen (1993) examines Miami’s growth from 1950s to 1990s and explains Miami's growth from a small resort town to a global city through a few consequential phenomena that occurred to help Miami grow into a global financial center and a place for headquarters of many international companies (Sassen, 1993). First, due to political circumstances in Latin America, Miami has witnessed large immigration flows, especially from Cuba, Nicaragua, Haiti, Panama, Colombia, and Honduras. Cuban immigrants, who belonged to the most privileged classes, soon started attracting companies to settle in Miami due to their bilingual characteristics, and started opening businesses themselves (Sassen, 1993). As a result, Miami started attracting more international companies, including the European banks and businesses, which contributed to excluding the previous inhabitants of Miami from economic activity, creating a niche for highly educated professionals from other areas of the US and the world. As mentioned in the previous chapter, Miami did not avoid gentrification and growing inequality, and according to Sassen (1993), the Cubans being excluded from non-Cuban corporation, and back population being excluded from higher positions in large-scale companies.

According to Wright and Donley (2011), such social devastation as homelessness in Florida resulted in a large part from drastic transformations that saw growth as the main priority in urban planning (Wright \& Donley, 
2011). As a result, the gap between the rich and the poor increased, with certain groups of society being continuously excluded from better employment opportunities and being pushed out of the districts where they cannot afford the rent anymore. According to Tonkiss (2013), Miami has a high level of urban inequality, which can be compared to that in the world's poorest cities (Tonkiss, 2013). According to the US Census Bureau, MiamiDade County's Gini Index was 0.5 in 2010, which indicates a high income inequality across the households (US Census Bureau, 2012).

Nijman (1997) explains how Miami's growth is a great example of rapid globalization with unplanned social consequences. Nijman (1997), similarly like Sassen (1993), links Miami's success in economic growth due to its Latin American connections. However, Nijman (1997) points out that "[a] city's economic growth does not benefit all its residents" (Nijman, 1997: p. 171). As a result, social problems that occur due to rapid globalization processes are not properly addressed, or only so if they pose a challenge on further economic growth (Nijman, 1997). Going back to the argument by Flint and Raco (2012), it is clear that Miami is an example of urban growth, where economic interests overshadow the need for social equity.

Nijman (2011) identifies that Miami is the top on the list by the transience index out of the 50 biggest cities in the US. The index is compiled of the numbers of in- and outmigration, the population living in the city for five or less years, population born out of the state and population with immigrant status, as well as foreign-born population (Nijman, 2011). In this way the rapid economic growth increases the exclusion of vulnerable groups, those lacking social and human capital, from employment opportunities and affordable housing. The economic characteristics of Miami-Dade County indicate that the region should expect continuing growth in the future. The Miami-Dade County's gross regional product (GRP) has been steadily increasing from 2003 to 2011, from $\$ 89,295$ million to $\$ 119,022$ million, respectively (Miami-Dade County, 2013). Therefore, it is evident that the social consequences that follow should be properly addressed. However, new developments only prove the fact that economic prosperity is the highest on the list of priorities for public officials.

One example is the Seven/50 project, which is a joint development project of seven counties, namely Monroe, Miami-Dade, Broward, Palm Beach, Martin, St. Lucie and Indian River, which teamed up in order to help ensure a vibrant and resilient economy. The main driving force for the project is the changing demographic characteristics of the area, as the population is projected to grow from 6 million in 2010 to roughly 9 million in 2060 (Seven50, 2014). It is intended to look extensively into the challenges that the area will be facing due to rapid population growth and possible solutions, of which most emphasis will be placed on sustainable development in areas of the community, economy as well as environment. Some important issues that city planners are dealing with are not primarily concerned with improving the walk ability of Downtown Miami as well as homeless presence that is that continues to persist Downtown.

The core of the project is community involvement, where community members are invited to contribute to developing the goals, objectives and actions for the key areas. However, as indicated in the previous chapters, the vulnerable community groups usually do not have the means or the information to have their voices heard. What is more, tackling homeless presence in the project is closely linked to homeless criminalization rather than accommodation strategies.

In 1992, the City of Miami lost a case against Pottinger and 6,000 other homeless plaintiffs, who sued the city for violation of the Eighth Amendment, which prohibits cruel and unusual punishment infliction. The lawsuit was triggered by an increase of police arrests of the homeless, prohibiting them to be "lying down, sleeping, standing, sitting or performing other essential, life-sustaining activities in any public place at any time" (Pottinger v. City of Miami, 1992). The court ruled in favor of the plaintiffs and concluded that "the City's practice of arresting homeless individuals for performing inoffensive conduct in public when they have no place to go is cruel and unusual in violation of the Eighth Amendment” (Pottinger v. City of Miami, 1992). As a result, the City's homeless were granted the right to carry out their life-sustaining activities due to involuntary homeless status.

However, with the Seven50 project, which is focused on sustainable economic development, the ruling has been challenged as dealing with homeless presence in Downtown Miami that intends to strip the homeless population off their rights. In January 2014, Miami Herald reported the settlement being reached between the American Civil Liberties Union and the Board of Miami-Dade County Commissioners, which, if signed by the federal judge, would significantly mend the rights that homeless people have been enjoying since the court ruling in 1992 (Miami Herald, 2014). In February 2014 the U.S. Judge Federico Moreno approved the changes (Miami Herald, 2014). 
As a result, homeless people could be arrested for building fires in parks to cook, or building tents to sleep in if there is shelter available for them. The Chairman of Homeless Thrust, Ron Book, criticized the plans (Miami Herald, 2014). The County provided funding for 100 new mats in the Camillus House shelter for short-time stays for homeless that fail to follow the new terms of agreement and are picked up by the police. The new terms of agreement were argued by the changes in the Miami Downtown area, which has enjoyed a significant increase in population and economic activity, with new restaurants, residential buildings, and an increase of tourists. Although the Board of Miami-Dade County Commissioners acknowledged the issue as both socially and economically important, the solution designed clearly preferred the economic interests over social: forcing out homeless people from Downtown Miami is a way of beautifying the area by removing the homeless people rather than directly dealing with social issues that vulnerable social groups face as a result of economic growth.

The numbers suggest that growth in Miami-Dade County will be steadily increasing, thus raising new issues of inequality and social exclusion, which should be more actively addressed not only by the advocates of the homeless, such as the Homeless Trust, but by the County officials as well. There are no quick fixes to the problem, and attempting to hide the consequences of economic growth priorities could only prolong, and possibly, end up in increasing the scale of the problem. Therefore, the creation of sustainable communities is a far-reaching goal.

\section{Discussion and Conclusions}

The article aimed to discuss the issue of homelessness in the light of sustainable development and sustainable communities, drawing from examples found in the literature and practice in the US, as well as Miami-Dade County in general.

It is evident that the issue of homelessness lacks both theoretical and practical interest, which can be challenged due to major challenges when identifying the scope of the problem, such as establishing an agreed-upon definition as well as the numbers of homeless that come close to reality.

The relevance of tackling the homeless presence is non-debatable: it is not only a responsibility of social and political actors to help relieve human suffering, but in the long-term, the need to develop adequate strategies stems from growing interest and applicability of the sustainable community and sustainable development approaches, where the needs of most vulnerable groups of society should be properly addressed. In the modern globalizing world, however, the need for social equity might be overshadowed by the challenges for larger economic growth.

Two main strategies to tackle homeless presence addressed, namely the accommodation and criminalization, differ greatly in their long-term sustainability. Utah's example demonstrates that quick and effective housing provision may be a sensible approach to tackle homelessness as opposed to housing approaches that require homeless people to transition from temporary to permanent housing. It may as well not be more costly than transitional approach, or criminalization. Homeless criminalization has been on the rise in the US, with the need for economic growth, homeless people have been displaced from particular areas or even cities or states due to the inability to exercise self-sustaining activities. The criminalization approach may be viewed as a temporary solution of city planners for area beautification purposes, but does not address the issue on the long-term, neither it is sustainable. Further, due to the federalist system of the US, there is more incentive for different states of counties to impose homeless criminalization laws to force the homeless to other areas.

The case study of Miami-Dade County demonstrated a number of different interests when tackling the issue of homelessness. Due to difficulty to establish the real numbers of the homeless, which are typically much greater than the official count, it becomes more difficult to secure adequate funding to deliver the required services and properly voice the homeless people's needs to the County when economic development plans are being made.

The analysis of Miami's rapid economic growth that has been evident over the past 60 years provided support for Flint and Raco's (2012) argument that the needs of most vulnerable society groups are usually pushed down on the political agenda to make place for increasing economic growth. One such example is the Seven50 long-term economic development project, which resulted in larger restrictions for homeless people in Downtown Miami in order to foster economic growth and make it more attractive for the residents as well as tourists. Therefore, such area beautification strategies offer direct support for Miami's priorities on political agenda, which, with continuing economic growth, are projected to be continuing in the near future. 
Although Homeless Trust that operates in Miami-Dade has been viewed as a successful representative of homeless people's rights and interests, an attempt to turn to other counties and states of the US, such as the successful case of Utah, should be on top of political agenda. More effective ways of tackling homelessness would not only contribute to the betterment of homeless people's lives, but in reaching goals to create more sustainable communities of higher social capital. Sustainable development, therefore, means effectively addressing social issues that can be at least partly associated with an increase of social inequality and economic development. Leaving the problems unsolved may result in a number of new unwanted challenges with even more complex and costly solutions.

\section{References}

Amster, R. (2003). Patterns of Exclusion: Sanitizing Space, Criminalizing Homelessness. Social Justice, 30, $195-221$.

Bella, C. L., \& Lopez, D. L. (1994). Quality of Life-At What Price? Constitutional Challenges to Laws Adequately Impacting the Homeless. Journal of Civil Rights and Economic Development, 40, 89-121.

Calsyn, R. J., \& Morse, G. A. (1991). Predicting Chronic Homelessness. Urban Affairs Quarterly, 27, 155-164. http://dx.doi.org/10.1177/004208169102700109

Council on Homelessness, Department of Children and Families (2013). Council on Homelessness 2013 Report. http://www.dcf.state.fl.us/programs/homelessness/docs/2013CouncilReport.pdf

Cozens, P. M. (2002). Development and Crime Prevention through Environmental Design for the British City: Towards an Effective Urban Environmentalism for the 21st Century. Cities, 19, 129-137. http://dx.doi.org/10.1016/S0264-2751(02)00008-2

Craig, T. K. J., \& Hodson, S. (2000). Homeless Youth in London: II. Accomodation, Employment and Health Outcomes After 1 year. Psychological Medicine, 30, 187-194. http://dx.doi.org/10.1017/S0033291799001488

Cunningham, K. (1999). Out of Sight-Out of Mind: A Report on Anti-Homeless Laws, Litigation and Alternatives in 50 United States Cities. Washington DC: National Law Center on Homelessness and Poverty.

Dale, A., \& Newman, L. (2010). Social Capital: A Necessary and Sufficient Condition for Sustainable Community Development? Community Development Journal, 45, 5-21. http://dx.doi.org/10.1093/cdj/bsn028

Department of Community Affairs of the State of Florida (2013). State of Florida Consolidated Plan Federal Fiscal Years 2011-2015. http://www.floridajobs.org/fhcd/cdbg/Files/ConsolidatedPlan/ConsolidatedPlanFor2011-2015.pdf

Department of Housing and Urban Development (2013). The 2013 Annual Homeless Assessment Report (AHAR) to Congress. https://www.onecpd.info/resources/documents/ahar-2013-part1.pdf

Flint, J., \& Raco, M. (2012). The Future of Sustainable Cities: Critical Reflections. Bristol: The Policy Press.

Frank, K. (2002). Historic Preservation in the USA. Berlin: Springer. http://dx.doi.org/10.1007/978-3-662-04767-5

Glass, R. (1964). London: Aspects of Change. London: MacGibbon \& Kee.

Harding, J., \& Willett, A. (2008). Barriers and Contradictions in the Resettlement of Single Homeless People. Social Policy and Society, 7, 433-444. http://dx.doi.org/10.1017/S1474746408004405

Hombs, M. E. (2001). American Homelessness: A Reference Handbook. Santa Barbara, CA: ABC-CLIO Inc.

Homeless Trust (2014). The Homeless Trust. http://www.miamidade.gov/homeless/

King, W. R., \& Dunn, T. M. (2004). Dumping: Police-Initiated Transjurisdictional Transport of Troublesome Persons. Police Quarterly, 7, 339-358. http://dx.doi.org/10.1177/1098611102250586

Levinson, D. (2004). Encyclopedia of Homelessness. Thousand Oaks, CA: Sage Publications, Inc.

Miami-Dade County (2013). Miami-Dade County: Economic and Demographic Profile 2013.

http://www.miamidade.gov/business/library/reports/2013-economic-demographic-profile.pdf

Miami Herald (2014). Miami Approves Settlement That Would Water down Homeless Rights. http://www.miamiherald.com/2014/01/09/3860479/new-rules-for-miami-homeless-and.html\#storylink=cpy

Miami Herald (2014). Miami’s Homeless Stripped of Some Rights as Judge Accepts Settlement. http://www.miamiherald.com/2014/02/28/3965387/miamis-homeless-stripped-of-some.html\#storylink=cpy

National Law Center on Homelessness and Poverty (2014). Criminalizing Crisis: The Criminalization of Homelessness in U.S. Cities. http://www.nlchp.org/documents/Criminalizing Crisis

Nijman, J. (1997). Globalization to a Latin Beat: The Miami Growth Machine. Annals of the American Academy of Political and Social Science, 551, 164-177. http://dx.doi.org/10.1177/0002716297551001012

Nijman, J. (2011). Miami: Mistress of the Americas. Philadelphia, PA: University of Pennsylvania Press. 
Pottinger v. City of Miami, 810 F. Supp. 155 S. D. Fla. (1992).

Raco, M. (2007). Building Sustainable Communities: Spatial Policy and Labour Mobility in Post-War Britain. Bristol: The Policy Press.

Rittel, H. W., \& Webber, M. M. (1973). Dilemmas in a General Theory of Planning. Policy Sciences, 4, 155-169. http://dx.doi.org/10.1007/BF01405730

Roseland, M. (2012). Toward Sustainable Communities: Solutions for Citizens and Their Governments. Gabriola Island, BC: New Society Publishers.

Rossi, P. H. (2013). Down and Out in America: The Origins of Homelessness. Chicago, IL: The University of Chicago Press. Sassen, S. (1993). Miami: A New Global City? Contemporary Sociology, 22, 471-477. http://dx.doi.org/10.2307/2074362

Seven50 (2014). About the Southeast Florida Regional Partnership. http://seven50.org/overview/about-the-southeast-florida-regional-partnership/

Substance Abuse and Mental Health Services Administration (2011). Current Statistics on the Prevalence and Characteristics of People Experiencing Homelessness in the United States. http://homeless.samhsa.gov/ResourceFiles/hrc_factsheet.pdf

Slumsky, N. L. (2012). Homelessness: A Documentary and Reference Guide. Santa Barbara, CA: ABC-CLIO.

Tonkiss, F. (2013). Cities by Design: The Social Life of Urban Form. Cambridge: Polity Press.

Thompson, W. N. (2005). Native American Issues: A Reference Handbook. Santa Barbara, CA: ABC-CLIO Inc.

United Nations (1987). A/RES/42/187 Report of the World Commission on Environment and Development.

United Nations Centre for Human Settlements (Habitat) (2000). Strategies to Combat Homelessness.

U.S. Census Bureau (2012). Household Income Inequality within U.S. Counties: 2006-2010. http://www.census.gov/prod/2012pubs/acsbr10-18.pdf

U.S. Department of Housing and Urban Development (HUB) (2010). Strategies for Improving Homeless People’s Access to Mainstream Benefits and Services.

U.S. Department of Housing and Urban Development (HUB) (2014). Homelessness Assistance. http://portal.hud.gov/hudportal/HUD?src=/program_offices/comm_planning/homeless

Utah Department of Community Services and Economic Development (2004). Ten-Year Strategic Action Plan to End Chronic Homelessness. http://utah.ptfs.com/awweb/awarchive?type=file\&item=26060

Utah Housing and Community Development Division (2012). Utah: Comprehensive Report on Homelessness. http://jobs.utah.gov/housing/documents/Utah2012ComprehensiveReportonHomelessness.pdf

Wright, J. D., \& Donley, A. M. (2011). Poor and Homeless in the Sunshine State: Down and Out in Theme Park Nation. New Brunswick, NJ: Transaction Publishers. 
Scientific Research Publishing (SCIRP) is one of the largest Open Access journal publishers. It is currently publishing more than 200 open access, online, peer-reviewed journals covering a wide range of academic disciplines. SCIRP serves the worldwide academic communities and contributes to the progress and application of science with its publication.

Other selected journals from SCIRP are listed as below. Submit your manuscript to us via either submit@scirp.org or Online Submission Portal.
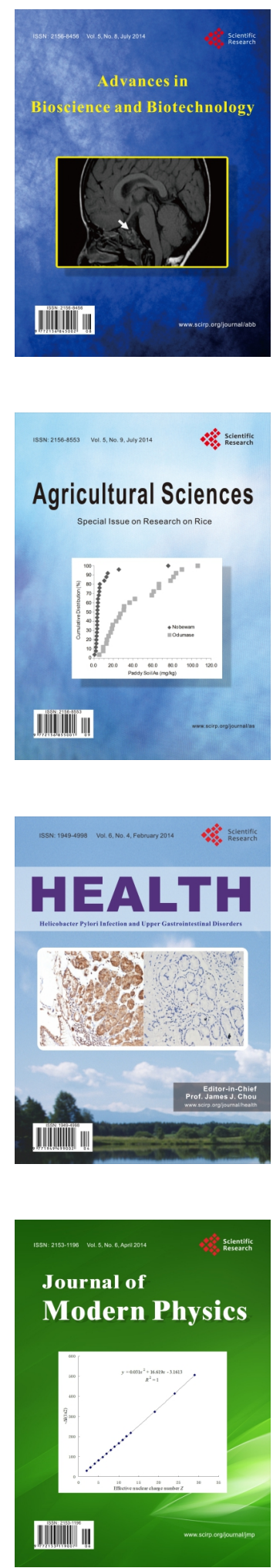
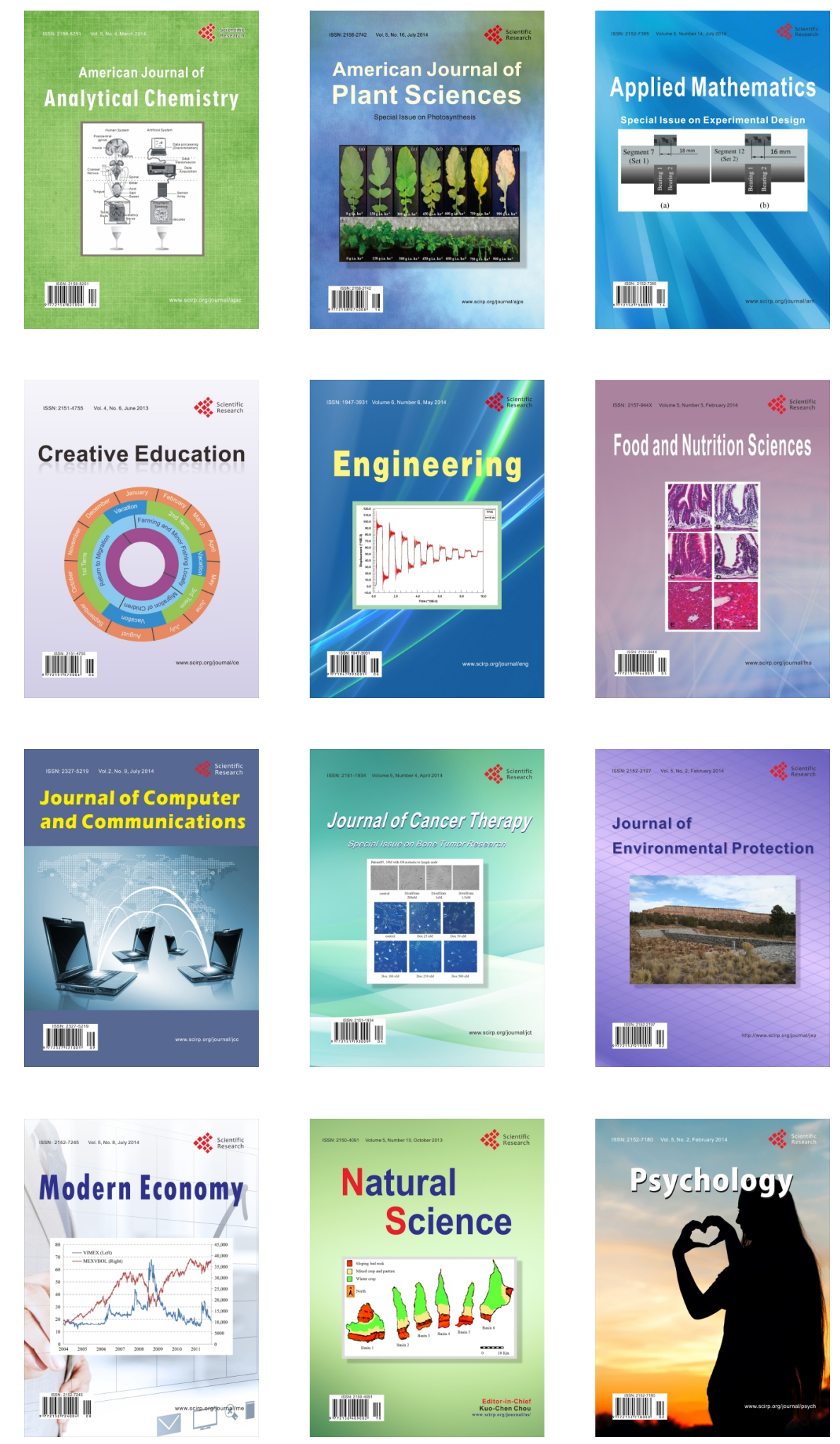